\title{
Perception of Employers' in Transforming Technical and Vocational Education and Training vis-a-vis Emerging Technology Tools for Sustainable Workforce Development in Nigeria
}

\author{
Oladiran Stephen Olabiyi ${ }^{1}$, Caleb Chidozie Chinedu ${ }^{2}$ \\ ${ }^{1}$ University of Lagos \\ 101017 University Road, Akoka, Lagos State, Nigeria \\ ${ }^{2}$ Universiti Tun Hussein Onn Malaysia \\ 101 Beg Berkunci, Parit Raja, Batu Pahat, Johor, 86400, Malaysia
}

DOI: $10.22178 /$ pos.33-6

LCC Subject Category:

LB5-45

Received 10.03.2018

Accepted 10.04.2018

Published online 22.04.2018

Corresponding Author:

Caleb Chidozie Chinedu

caleb4life56@gmail.com

(C) 2018 The Authors. This

article is licensed under a

Creative Commons

Attribution 4.0 License

\begin{abstract}
Economic competitiveness of a country depends to a large extent on the skills of its workforce. The skills and the competencies of the workforce, in turn, are dependent upon the quality of the country's education and training. Education and training are undergoing continuous change, and this change poses more challenges to the 21 st-century workforce, and to training institutions. Despite the importance of TVET in transforming economic development, of any nation, Nigeria still has different perspectives about the competency of its TVET graduates. Therefore, the paper aims at determining the perceptions of Organized Private Sector (OPS) employers' regarding the competency of TVET graduates and the role of emerging technology tools in transforming TVET for a sustainable workforce development. Using a descriptive survey research design and a sample of 80 OPS employers. A validated and piloted questionnaire based on a 5-point Likert scale used as the data collection instrument for the study. Data were analysed using descriptive and inferential statistics including means, standard deviation and ANOVA. Data analysis was facilitated using the Statistical Package for Social Sciences (SPSS). Findings revealed that employers were not satisfied with the competency level of TVET graduates as it is showed that they are not well prepared to enter the competitive workforce and to be self-reliant. Given the nature and complexity of the field of TVET for a sustainable workforce, it was recommended that the utilization of adequate planning and management of emerging technology tools and resources in teaching TVET programs could contribute enormously to the quality and sustainability of the Nigerian workforce.
\end{abstract}

Keywords: Technical and Vocational Education and Training; workforce development; Organized Private Sector (OPS); technology tools.

\section{INTRODUCTION}

The major challenge that faces the country is the development of a competent workforce for sustained economic growth in the global economy. Workforce development, through a well-planned and orchestrated education and training initiative, will contribute significantly to promoting the interests of individuals, employers, enterprises, the economy and society within such country. A well-structured Technical Vocational
Education and Training (TVET) system will enable productivity, enhance competitiveness and promote entrepreneurial activity [3]. The purpose of TVET is to prepare people for selfemployment and to serve as a medium of evolution for people in the world of work; by enabling individuals to develop a sense of belonging in their communities. Furthermore, according to [15], TVET is regarded as an instrument for reducing extreme poverty. These distinctive features of TVET make the application and utiliza- 
tion of technology tools a mandatory component that can transform TVET to achieve a sustainable and globally recognized workforce within a nation. The [31] and the [11] defined TVET as a comprehensive term referring to those aspects of the educational processes involving, in addition to general education, the study of technologies and related sciences, the acquisition of practical skills, attitudes, understanding and knowledge relating to occupations in various sectors of economic and social life.

TVET is otherwise regarded as workforce education, particularly, in a more traditional role, it facilitates the adjustment of the skills and knowledge of man to the changing demands of the society. It places emphasis on skill development of the individuals in a chosen occupation [24]. TVET, therefore, has an important role to play in raising the quality of work and competency of TVET graduates, increasing job satisfaction and motivating workers as well as enhancing their productivity [18]. Put succinctly, TVET prepares individuals for the ever-changing world of work. Effective participation in the world of work is made feasible with the adoption of adequate technology tools in TVET institutions. TVET the 'study of technologies and related sciences' as reflected in the definition above becomes the guiding principle with which TVET institutions should strive to accomplish by making available the required technology tools across TVET institutions. The development and application of emerging technology tools in TVET have been one of the major areas emphasized by UNESCO, since technology tools are becoming inexpensive, reachable and interactive, whereby their integration into all levels of education is expected to be practical in making educational results labourmarket oriented, and in the transformation of contents, methodology, as well as promoting information literacy. With information literacy predicted as being tantamount to human survival [2].

Technology tool in the view of [21] are tools that comprise electronic devices which are utilized for the information and communication needs of an institution, organizations, staff as well as students. Electronic devices in this regard are computers (software and hardware), networking, telephone, video, multimedia and the internet. These devices can be converted from their raw form (e.g. text messages, sounds and motion) to common digital forms for use. Similarly, [16] described technology tools in relation to education as those technologies (radio and television), video, Digital Versatile Disk (DVD), telephone (both fixed line and mobile phones), satellites systems, computer network (hardware and software), as well as the equipment and services associated with these technologies. Prominent among such technologies are video conferencing tools and the electronic mail. Furthermore, emerging technology tools according to [8] facilitate the development and strengthening of TVET around the world by enhancing networking and knowledge sharing opportunities. The implication is that it enables and strengthens TVET institutions to further deploy and reinforce their commitment toward training and producing technology capable graduates that will meet the challenges of virtual workplaces. Thus, knowledge in the exploitation of technologies is critical in present-day workforce development. One of the possible means for transforming TVET to develop a sustainable workforce for the everdynamic world of work is to focus on the use of emerging technology tools in the curriculum implementation process.

According to the World Commission on Environment and Development (WCED), as reported in [5], the concept of sustainability is the result of a balance between resource consumption and reproduction. To fulfil our obligations to the younger generation and maintaining a stable community, each generation must develop within its citizens, the competencies and skills for sustainable living, to ensure that community resources are kept at optimal levels and are passed down undiminished. Sustainable development refers to a mode of human development in which resource use is conserved and maintained to meet human needs while preserving the health of living and environment conditions so that these needs can be met not only in the present but also for generations to come [13]. As such, the need for emerging technology tools in TVET remains a great challenge, considering the impact it can make in the training and development of knowledgeable workers skilled in information technologies [27]. In other words, the use of technology tool in the training, up-grading and retraining of workers is of paramount significance and an essential aspect of teaching cultural toolkit for the twenty-first century, as this affords new and transformative models of development [17]. The organised private sector (OPS) is one of the major stakeholders of TVET, as they contribute to determining important skill needs in spe- 
cific vocations that can, in turn, be used to redesign training programs to further equip graduates with the needed skills and competencies to function in the twenty-first century workplace. The author [23] explained that the organised private sector consists of those businesses and industrial set-up where government participation by way of ownership is zero or near zero percent. They are businesses initiated, funded and managed by private individual or groups. They cut across all the sectors of the economy including agriculture, commerce, manufacturing, mining, services and education.

\section{Statement of the problem}

The socio-economic changes, unemployment and lack of skilled workers in many nations of the world pose challenges to TVET institutions and the industrial sector. This trend has given rise to economic, political and social crises that are threatening the political and economic stability of many nations, and the changing workforce has also placed a demand on TVET institutions to produce educated, motivated, skilled-based to the ICT-capable workforce. The author [20] stressed that training in TVET institutions should strengthen their practical element with emphasis on social and practical skills development. Despite the significance of TVET in national workforce development, employers still have varying perspectives about the competency of TVET graduates. An international comparison shows that employers in the United States of America and the United Kingdom believe that the present state of TVET programme in their respective countries is inadequate to train students effectively for the changing demands of the workplace $[4,9]$. However, Australian employers are reported as being satisfied with their TVET programme in the training of workers for the nation's workforce [10]. This may be as a result of a more comprehensive and standardized TVET training system.

The problem of workforce development according to the [12], is hinged on the inadequacies in the preparation of TVET graduates in terms of delivering TVET competency-based curriculum and the lack of relevant skills in the use of emerging technology tools [24]. The existing training curricula and pedagogies used in training institutions are inadequate and in many respects do not fully meet industrial requirements [3]. This existing training systems produce a workforce that lags basic skills required for gaining employment [10]. The success of a TVET system has been established to be enormously dependent on the utilization of emerging technology tools. This allows industries to assume ownership of a more effective approach to TVET and allows them to invest in the TVET institutions in terms of a lending continued support about what is obtainable in industries and awareness of current technological tools needed [12]. To bridge the gap between industry requirements and training in TVET institutions, there is a need for TVET institutions to incorporate and use emerging technological tools to transform how TVET graduates are trained in order to enable a sustainable workforce that meets the needs of the nation. Therefore, this study attempts to ascertain employers' perception of transforming TVET through emerging technology tools to for a sustainable workforce development, and to determine their perceptions regarding the competency level of TVET graduates in Nigeria.

The purpose of the study was to determine organised private sectors (OPS) employers' perception regarding the competency of TVET graduates and the role of emerging technology tools in transforming TVET for sustainable workforce development.

\section{Research Questions}

1. What are the perceptions of employers regarding the competency of TVET graduates for ensuring sustainable workforce development?

2. What are the perceptions of employers' regarding the role of emerging technology tools in transforming TVET for sustainable workforce development?

3. Do OPS employers perception of the competency of TVET graduate differ in terms of computer experience and working experience?

\section{Review of related literature}

In recent years, technology tools have emerged in teaching and learning practice in many educational institutions across the globe. This phenomenon has taken place as a response to economic, social and pedagogical pressures [22]. From an economic standpoint, it is believed that knowledge and competence in technology will enhance graduates' opportunity to be professionally employed [29]. Indeed, it is argued that the measured level of employability will 
strengthen the economy of a nation [14]. Similarly, the social basis for competence in the use of technology is considered a necessary skill for TVET graduates to participate in community development [22]. This can enable students to lead the society to meet the challenges of the information age. The pedagogical basis for developing competencies in technology is that its integration in education will facilitate a transformation in the teaching and learning process from teacher centred pedagogies to more student-centred pedagogies [30]. The student-centred environment is arguably more result-oriented and favourable than the teacher-centred learning environment because it provides learners with the opportunities to actively participate in knowledge construction [26].

Emerging technologies have become a powerful tool for TVET programmes around the world. In this context, UNESCO [31] recommended that optimal use of these technological tools should be based on modern-day innovations, particularly the Internet, interactive multimedia materials, audio-visual aids and mass media, to enhance cost-effectiveness, quality and richness of TVET programmes, especially for the promotion of selflearning. It is therefore essential that TVET teachers model the appropriate use of emerging technology resources in the workshop and classroom to help equip TVET graduates with the necessary knowledge and skills to utilize these tools in their work life. Technology tools in the views of [1] are new communication and computing technology used for creating, storing, selecting, changing, developing, receiving and displaying any kinds of information. Technology tools are those related to the use of computers and the ability to transmit stored information through fixed line networks or through wireless phone networks. Thus, it involves three steps of receiving digital information, storing it and afterwards reshaping and resending the information.

Digital information can be described as any communication whether written, audio or video. With this, [31] proposed that TVET institutions need to develop strategies and plans to transform the teaching and learning process within TVET programmes and ensure that all future TVET graduates are well prepared to use emerging technology tools for learning. TVET needs to be revitalized and transformed in order for it to become an avenue to provide effective and adequate training for individuals while imparting the necessary skills for these individuals to become self-reliant in all endeavours [11]. TVET should also be transformed vis-à-vis the adoption of emerging technology tools so that it can be used to offer thorough and specialized training to individuals for employment, including selfemployment [31]. Perception according to [23] refers to the manner in which one thinks about something and ones' idea of what that thing constitutes. It can also be described as the ability to understand the true nature of a subject especially as it affects our environment. Since learning is a process which is characterized by a series of changes in behaviour or a change in behaviour that result from an activity, training or observation. It is therefore expedient to explore the perceptions of OPS employer's regarding the competency of TVET graduates in Nigeria and the perceived usefulness of technology tools in the training of TVET graduates.

Workforce development is a process used to align the needs and priorities of an organisation with those of its workforce to ensure that it can meet its legislative, regulatory, service and production requirements as well as organizational objectives [28]. Workforce development has evolved from a problem-focused approach, addressing issues such as low-skilled workers and the need for more employees in a particular industry, to a holistic approach constituting participants' many barriers and the overall needs of the region [19]. Today workforce development often is seen as a solution to issues of social equity. Historically, it has existed in two forms: place-based strategies that attempt to address the needs of people living in a particular neighbourhood, or sector-based strategies that focus on matching workers' skills to needs in an industry already present in the region, such as healthcare or manufacturing. Some contemporary workforce development programs attempt to combine elements of both approaches, linking employment training with other government programs and community resources to provide wrap-around services. Preparing individuals for the highly digital world they are introduced to upon graduation from TVET institutions requires competencies on the use of emerging technology tools. Employees with emerging technology skills and competencies are highly demanded and are considered valuable human capital assets to companies than those who do not meet this requirement. 
Because of the lack of skills in emerging technology use, many workers who are well respected and regarded as educated find themselves grouped alongside those who are considered non-literate workers. The increasing complexity of modern workplaces and contemporary life means that for many, making the most of this opportunity include taking steps to strengthen their skills in the use of emerging technology. TVET graduates without skills in emerging technology may not have good job success, which is tantamount to placing employability barriers in their path. Allowing students to graduate with these skill deficiencies has far-reaching implications for their careers. Hence, in preparing students for successful and productive participation for the world of works, TVET institutions have an enormous responsibility in ensuring that these graduates are better equipped to face the challenges that lie in their future careers [7]. TVET graduates need to be assisted and prepared satisfactorily for initial and continued employment through the adoption of technology tools for workforce development. TVET graduates must be competent to select technology tools, judging which set of procedures, tools, or machines, including computers and their programs, will produce the desired results for various tasks or goals. They should be skilled in applying technology tools to task by understanding its overall intent and the proper procedures for setting up and operating machines, including computers and their programming systems, while also maintaining and troubleshooting technology to prevent damage, identify or solve specific issues in machines, computers, and other technologies.

We are living in a constantly evolving digital world. The digital age has transformed the way young people communicate, network, seek help, access information and learn. We must recognize that young people have now become a digital populace and access to all lot of resources has now become through technology tools such as computers, TVs and mobile phones. As technology becomes more and more embedded in our culture, we must provide our learners with relevant and contemporary experiences that allow them to successfully engage with technology and prepare them for life after school. It is widely recognised that learners are motivated and purposefully engaged in the learning process when concepts and skills are underpinned by technology and sound pedagogy [12].

\section{METHODS}

This study employed a descriptive survey research design. Eighty organised private sector employers in Lagos state, Nigeria were randomly selected to participate in the study. The instrument for data collection was a structured questionnaire. The instrument had four sections A to D. Section A sought information on personal data of the respondents such as years and working experience. Section B to D sought information on the three research questions. The questionnaire was subjected to face and content validation by three experts. The internal consistency of the instruments was determined using Cronbach Alpha, with an alpha value of $\alpha=.88$. The instrument was administered to the respondents through research assistants and personal contact. Out of 80 questionnaires administered, 76 were duly filled and returned to the researcher. These represented $95 \%$ questionnaire retrieval rate. Data generated from the questionnaire were analysed using descriptive and inferential statistics, particularly mean, SD and ANOVA at 5\% level of significance, through the Statistical Package for Social Sciences (SPSS) version 20.

\section{RESULTS AND DISCUSSION}

Perceptions of the Organised Private Sector (OPS) employers regarding the competency of TVET graduates in using emerging technology tools for ensuring a sustainable workforce development (Table 1).

Table 1 presents the mean and standard deviation of employer's perception in the organized private sector regarding the competency of TVET graduates for in using emerging technology tools. The overall mean score of 2.95 shows that employers in OPS indicated that employees are not competent in using emerging technology tools for economic development. Among which include: competency to use computer-aided design (CAD) to draw and install fittings and patterns on constructed projects; using computers with numerical control machines, and robots to carry out mass production of projects; skills in using computer-aided manufacturing (CAM) for manufacturing of projects in the workshop. The following items on the scale had mean values ranging from 1.77 to 3.38 which is below the cut-off point of 3.50 on the \%point Likert scale. 
Table 1 - Perception of OPS employers regarding the competency of TVET Graduates $(\mathrm{N}=76)$

\begin{tabular}{|c|l|c|c|}
\hline No & \multicolumn{1}{|c|}{ Items } & Mean & SD \\
\hline Compt. 1 & $\begin{array}{l}\text { Competent in using computer-aided design (CAD) software to draw and install } \\
\text { fittings and patterns on constructed projects. }\end{array}$ & 2.30 & .95 \\
\hline Compt. 2 & $\begin{array}{l}\text { Ability to use emerging technology tools with spraying machine for the } \\
\text { application of finishes to finished products. }\end{array}$ & 3.00 & .72 \\
\hline Compt. 3 & $\begin{array}{l}\text { The capacity to design homes and other products electrically using computer- } \\
\text { aided design (CAD) software }\end{array}$ & 1.77 & .21 \\
\hline Compt. 4 & $\begin{array}{l}\text { Skills in using truss design programme to prepare bills of materials for design } \\
\text { and construction of proposed products. }\end{array}$ & 2.90 & .50 \\
\hline Compt. 5 & $\begin{array}{l}\text { Skills in preparing cost, keeping detailed records to track budget performance } \\
\text { and making appropriate adjustments. }\end{array}$ & 1.94 & .63 \\
\hline Compt. 6 & $\begin{array}{l}\text { Using computers with numerical control machines, and robots to carry out mass } \\
\text { production of projects. }\end{array}$ & 2.90 & .30 \\
\hline Compt. 7 & $\begin{array}{l}\text { Skills in creating decorations and model of structures using numerical control } \\
\text { router on designs. }\end{array}$ & 2.70 & .20 \\
\hline Compt. 8 & $\begin{array}{l}\text { Skills in using computer-aided manufacturing (CAM) for manufacturing of } \\
\text { projects in the workshop }\end{array}$ & 2.55 & .52 \\
\hline Compt. 9 & $\begin{array}{l}\text { lompetent to use computer-aided design (CAD) in keeping track of large } \\
\text { inventories of items in the workshop }\end{array}$ & 2.95 & .46 \\
\hline Compt. 10 & $\begin{array}{l}\text { Skills in using light application by stimulated emission of radiation (LASER) for } \\
\text { various manufacturing process e.g. cutting of materials to precise size. }\end{array}$ & 3.38 & .53 \\
\hline Compt. 11 & $\begin{array}{l}\text { Ability to store and recall different types of materials to be used in a particular } \\
\text { project. } \\
\text { Total }\end{array}$ & 3.34 & .77 \\
\hline & 2.95 & .46 \\
\hline
\end{tabular}

\section{Perceptions of OPS employers regarding the role of emerging technology tools in transforming TVET for a sustainable workforce development}

To determine the perceptions of employers regarding the role of emerging technology tools in transforming TVET for a sustainable workforce development, mean and SD were used to summarize the responses of the OPS employers and to determine their level of agreement or disagreement with each of the items presented in the questionnaire. The mean and SD are presented in Table 2 below.

Table 2 - Perception of OPS employers regarding the role of emerging technology tools in transforming TVET for sustainable workforce development $(\mathrm{N}=76)$

\begin{tabular}{|c|l|c|c|}
\hline No & \multicolumn{1}{|c|}{ Items } & Mean & SD \\
\hline Role 1 & $\begin{array}{l}\text { Access to emerging technologies strengthen the relevance of TVET to the increas- } \\
\text { ingly digital workplace }\end{array}$ & 4.08 \\
\hline Role 2 & $\begin{array}{l}\text { Emerging technologies allow global teams to work on different components of a } \\
\text { product simultaneously }\end{array}$ & 4.70 & .51 \\
\hline Role 3 & $\begin{array}{l}\text { Wider availability of best practices and best course materials in TVET can be shared } \\
\text { through emerging technology which fosters better teaching }\end{array}$ & 3.71 & .61 \\
\hline Role 4 & $\begin{array}{l}\text { lomputer-assisted design and manufacturing software speed up decision making in } \\
\text { industries }\end{array}$ & 3.58 & .52 \\
\hline Role 5 & $\begin{array}{l}\text { Through emerging technology tools, the mode of TVET curricula evolves from con- } \\
\text { tent-centred to competency-based and increases workforce development }\end{array}$ & 4.34 \\
\hline Role 6 & $\begin{array}{l}\text { Emerging technology tools remove potential barriers that are causing problems of } \\
\text { poor performance of TVET graduates }\end{array}$ & 3.56 & .86 \\
\hline Role 7 & $\begin{array}{l}\text { Emerging technology tools play a major role in the shift of curriculum delivery from } \\
\text { teacher delivery to students' delivery forms }\end{array}$ & 3.71 \\
\hline
\end{tabular}




\begin{tabular}{|c|l|c|c|}
\hline No & \multicolumn{1}{|c|}{ Items } & Mean & SD \\
\hline Role 8 & $\begin{array}{l}\text { Emerging technology tools increase motivation and engagement of students by fa- } \\
\text { cilitating the development of workforce skill }\end{array}$ & 3.82 \\
\hline Role 9 & $\begin{array}{l}\text { Technology tools such as Computer Aided Design (CAD) tools can be used to aid the } \\
\text { design of plans and products. }\end{array}$ & 4.08 \\
\hline Role 10 & $\begin{array}{l}\text { Helps to keep students on task as technology enhances meaningful construction of } \\
\text { knowledge and work }\end{array}$ & 4.27 \\
\hline & Total & 4.35 & .47 \\
\hline
\end{tabular}

Table 2 shows the mean responses of the perception of OPS employers' regarding the role of emerging technology tools in transforming TVET for sustainable workforce development. The role of emerging technology tools identified through the study includes: access to emerging technologies strengthens the relevance of TVET to the increasingly digital workplace; wider availability of best practices and best course materials in TVET can be shared through emerging technology which fosters better teaching; through emerging technology tools, the mode of TVET curriculum changes from content-centred to competencybased and increases workforce development; Technology tools such as Computer Aided Design (CAD) tools can be used to aid the design of plans and products. With means values ranging from 3.56 to 4.70 above the cut-off point of 3.50 , it was evident that the OPS employers considered emerging technology tools pertinent to the training of TVET graduates for a sustainable workforce development.

\section{OPS Employers' Perception of TVET Graduates Competency by Computer Experience}

To determine whether the responses of OPS employers regarding the competency of TVET graduates differ when their computer experience is used as criteria for estimating the difference, the Analysis of Variance (ANOVA) was used to ascertain that difference. OPS employers' computer experience was classified into four groups: 0-1 year, 1-3 years, 3-5 years and 5 years and above. Conditions that satisfy the use of ANOVA were maintained and adhered to. Hence, the result of the statistical analysis is presented below in Table 3.

Table 3 shows the result of ANOVA comparing the responses of OPS employers by computer experience. Results show that there was a statistically significant difference in OPS employers' perception of the competency of TVET graduates based on the computer experience with $(\mathrm{F}=.122 .764, \rho<.05)$.

Table 3: Difference in OPS Employers Perception of TVET Graduates by Computer Experience

\begin{tabular}{|l|c|c|c|c|c|}
\hline Comp. Exp. & $\mathrm{N}$ & $\overline{\mathrm{X}}$ & $\mathrm{SD}$ & $\mathrm{F}$ & $\rho$ \\
\hline $0-1$ & 15 & 3.68 & .13 & & \\
\hline $1-3$ & 26 & 4.15 & .03 & 122.764 & .000 \\
\hline $3-5$ & 17 & 4.71 & .24 & & \\
\hline 5 yrs and above & 18 & 4.78 & .21 & & \\
\hline
\end{tabular}

Post-hoc comparisons using Scheffe test indicated that the mean score for Group 3 and Group 4 was significantly different from those of Group 1 and Group 2. The results indicated that the perception of OPS employers' regarding the competency of TVET graduates in using emerging technology tools was influenced by their computer experience.

\section{OPS Employers' Perception of TVET Graduates Competency by Working Experience}

A one-way Analysis of Variance (ANOVA) was computed to compare the mean scores of OPS employers' perception of TVET graduate's competency in sustaining workforce development using the working experience as a factor for estimating the difference. OPS employers' working experience was divided into three groups: 0-5 yrs (group 1), 5-10 yrs (group 2), and 10 yrs. and above (group 3)). The output of the Analysis of Variance is summarized and presented in Table 4.

Table 4 - Difference in OPS Employers' Perception of TVET graduates by Working Experience

\begin{tabular}{|l|l|l|l|l|l|}
\hline Working experience & $\mathrm{N}$ & $\overline{\mathrm{X}}$ & $\mathrm{SD}$ & $\mathrm{F}$ & $\rho$ \\
\hline $0-5(1)$ & 28 & 3.73 & .33 & & \\
\hline $5-10(2)$ & 37 & 3.82 & .17 & 99.836 & .000 \\
\hline 10 yrs. \& above (3) & 11 & 4.56 & .39 & & \\
\hline
\end{tabular}


Table 4 shows the result of the ANOVA for OPS employers' perception of TVET graduates by working experience. Results indicated that there was a significant difference between the perception of OPS employers' regarding the competency of TVET graduates when working experience is used as a factor in estimating the difference $(F=99.836, \rho<.05)$. The results showed that working experience influenced OPS employers' perception of competency of TVET graduates for sustainable workforce development.

Determining employers' perception regarding the competency of TVET graduates and the role of emerging technology tools in transforming TVET for sustainable workforce development was the main goal of the study. Findings from the results presented in Table 1, revealed that Nigerian employers in organised private sectors (OPS) are not satisfied with the performance of TVET graduates in Nigeria. They emphasised that the present TVET programmes have not prepared competent skilled and semi-skilled workers on the use of emerging technology and the development of its associated skills to satisfy the needs of the Nigerian workforce. This finding is consistent with the perception of [4] who believed that the state of TVET in the US and UK was inadequate to train students effectively for the changing demands of the workplace. However, this finding negates the views of [10] who reported that Australian and Malaysian employers respectively were satisfied with their TVET system. Furthermore, it was revealed that TVET has not reduced unemployment in Nigeria. The implication of these findings is that there is an urgent demand for the Federal Government and the Organized Private Sector to step up efforts to upgrade the quality of TVET programmes in $\mathrm{Ni}$ geria. Employers in Nigeria believed that TVET graduates are not well prepared to enter the competitive workplace and do not possess technology associated skills.

Regarding employers' perceptions of the role of emerging technology tools in transforming TVET for sustainable workforce development, OPS employers believe that emerging technology tools are essential in transforming TVET programmes in producing a competent workforce for sustaining the economic development of the nation. They note that emerging technology tools change the entire focus of manpower needs in the world from skill-based to a technology capable workforce and increases motivation and engagement by facilitating the acquisition of workforce skill.
These findings are congruent with the opinion of [27] who emphasised that if technology tools are to make an impact in the world of work, then there is also a need for knowledgeable workers skilled in information technologies. The implication of this is that the use of technology tools in the training, up-grading and re-training of workers is of paramount significance and an essential aspect of the cultural toolkit for teaching in the twenty-first century. Reference [8] stressed that technology tools facilitate the development and strengthening of TVET around the world by enhancing networking and knowledge sharing opportunities. The implication of this for TVET institutions is that they can further deploy and strengthen their commitment towards training and produce technology capable graduates that will meet the challenges of the 21st century workplaces.

\section{CONCLUSION AND RECOMMENDATIONS}

TVET is considered a tool for reducing extreme poverty. This distinctive feature of TVET with the addition of emerging technology tools as a mandatory component makes it TVET more potent toward creating a more sustainable and globally recognized workforce. The present study investigated OPS employers' perception regarding the competency of TVET graduates and the role of emerging technology tools in transforming TVET for sustainable workforce development. Based on the analysis presented in this paper, the paper draws its conclusion that emerging technology tools are globally recognized tools needed for $\mathrm{Ni}$ geria to address the socio-economic and technological changes currently taking place in the world. TVET graduates must be vast in using emerging technology tools to enhance their productivity. Government and TVET institutions should focus on using emerging technology tools for learning instead of learning about emerging technology tools as this can provide wider availability of best practices and best course materials in TVET. It was recommended that to acclimatize TVET institutions to develop human resources for the ever-dynamic world of work, here is a need for the government and TVET stakeholders to focus investment in the use of emerging technologies in the curriculum implementation process. In conclusion, financial assistance should be given to assist TVET institutions and students in acquiring their personal technology tools for practical use in the delivery TVET courses and programmes. 


\section{REFERENCES}

1. Adewoyin, J. (2009). The Place of Information and Communication Technology in Designing and Utilising Instructional Materials. One Day Train the Trainer Open Workshop, 48-68.

2. Asian Development Bank. (2009). Good Practice in Information and Communication Technology for Education. Mandaluyong City, Philippines: Asian Development Bank.

3. Boodhai, N. (2009). Concept paper for the development of a CARICOM strategic plan for vocational education services in the CARICOM Single Market and Economy (CSME). Trinidad \& Tobago: Arthur Lok Jack Global School of Business.

4. Brown, A., \& Keep, E. (1999). A UK perspective on how well initial vocational education and training facilitates lifelong learning. Retrieved from http://www.leeds.ac.uk/educol/documents/000001135.htm

5. Brundtland, G. H. (1987). Our Common Future - Call for Action. Environmental Conservation, 14(04), 291. doi: $10.1017 / \mathrm{s} 0376892900016805$

6. CANTA Secretariat. (2005). CARICOM process for workforce training, assessment and certification. Kingston, JAMAICA: CANTA.

7. CARICOM. (2001). Regional Strategy for Technical and Vocational Education and Training. Barbados: Ministry of Labour and Social Security.

8. Collins, A., \& Halverson, R. (2009). Rethinking education in the age of technology: The digital revolution and schooling in America. New York: Teachers College Press.

9. Distler, J. A. (1993). Attitudes and perceptions of Maryland's mid-shore employers toward vocational education and employment training programs (Unpublished Doctoral Dissertation). Temple University.

10. Fairwealther, P. (1999). Employers perceptions of training and the way forward. In C. Robinson \& K. Arthy (Eds.), Lifelong learning: Developing a Training Culture (pp. 23-38). Leabrook, South Australia: NCVER.

11. Federal Republic of Nigeria. (2004). National Policy of Education (4th ed.). Nigeria: NERDC.

12. Gregory, R. (2003). The role of TVET and the Caribbean Association of National Training Agencies (CANTA) and allied bodies within the Caribbean Single Market and Economy (CSME). Caribbean Association of National Training Agencies, 3.

13. Griggs, D., Stafford-Smith, M., Gaffney, O., Rockström, J., Öhman, M. C., Shyamsundar, P., ... Noble, I. (2013). Sustainable development goals for people and planet. Nature, 495(7441), 305-307. doi: $10.1038 / 495305 a$

14. Haslem, J. A., Baker, H. K., \& Smith, D. M. (2006). Identification and Performance of Equity Mutual Funds with High Management Fees and Expense Ratios. SSRN Electronic Journal. doi: 10.2139/ssrn.2053801

15. Hollander, A., \& Mar, N. Y. (2009). Towards Achieving TVET for All: The Role of the UNESCOUNEVOC International Centre for Technical and Vocational Education and Training. International Handbook of Education for the Changing World of Work, 41-57. doi: 10.1007/9781-4020-5281-1_3

16. Khan, M., Hossain, S., Hasan, M., \& Clement, C. K. (2012). Barriers to the introduction of ICT into education in developing countries: The example of Bangladesh. International Journal of Instruction, 5(2), 61-80.

17. Leach, J. (2005). Do new information and communication technologies have a role to play in achieving quality professional development for teachers in the global south? Curriculum Journal, 16(3), 293-329. doi: 10.1080/09585170500256495 
18. Manfred, T., \& Jennifer, W. (2004). Vocational Education and Training key to the Future. Greece: Colibri Ltd.

19. Meléndez, E. (2004). Communities and workforce development. Kalamazoo, Michigan: MWE Upjohn Institute for Employment Research.

20. Michael, A. (2002). Developments in the Field of Vocational Education and Training (VET) System of Brussels: Member States. European Center for the Development of Vocational Training.

21. Nwankwundo, C., Oguejiofor, U., \& Nwankwo, C. (2006). NUC Executive Secretary Commission ICT Centre. Unizik Comment, 8(3), 6.

22. OECD. (2000). A new Economy?: The changing role of innovation and information technology in growth. Paris: OECD Publishing.

23. Okorie, J. U. (2000). Developing Nigeria Workforce. Calabar: Page Environs Publishers.

24. Olaitan, S. O. (1993). Essential considerations for an effective vocational - technical education development in Nigeria: At 8th Annual Conference of Nigerian vocational association at university of Uyo, Akwa Ibom State.

25. Olaitan, S. (1996). Vocational and technical education in Nigeria: issues and analysis. Onitsha: Noble Graphic Publishers.

26. Roblyer, A., Edward, P. O., \& Havriluv, G. (2004). An assessment of the skill needs of industry: a case study of Trinidad and Tobago. IVETA Conference, Jamaica.

27. Rojewski, J. W. (2009). A conceptual framework for technical and vocational education and training. In International handbook of education for the changing world of work (pp. 19-39). doi: 10.1007/978-1-4020-5281-1_2

28. Sloan, J. (2010). The workforce planning imperative. Adelaide: Julie Sloan Management.

29. Thornburg, D. D. (2002). The new basics: Education and the future of work in the telematic age. Virginia, USA: ASCD.

30. Trucano, M. (2005). Knowledge maps: ICT in education. Washington, DC: infoDev / World Bank.

31. United Nations Educational Scientific and Cultural Organization. (2002). Technical and Vocational Education and Training in the 21st Century: New Roles and Challenges for Guidance and Counselling. Retrieved from http://unesdoc.unesco.org/images/0013/001310/131005e.pdf 